DOI: $10.32702 / 2307-2105-2019.10 .4$

УДК 65.011.330.621.391

Н. Ю. Подольчак,

д. е. н., професор, завідувач кафедри адміністративного та фінансового менеджменту,

Національний університет «Львівська політехніка»

ORCID: 0000-0002-0284-9601

О. І. Білик,

к. е. н., дочент кафедри адміністративного та фінансового менеджменту,

Національний університет «Львівська політехніка»

ORCID: 0000-0002-7110-7257

Я. В. Левицька,

аспірант, Національний університет «Львівська політехніка», м. Львів

ORCID: 0000-0001-7133-7602

\title{
СУЧАСНИЙ СТАН ЦИФРОВІЗАЦІЇ В УКРАЇНІ
}

\author{
N. Yu. Podolchak \\ Doctor of economic Sciences, Professor, \\ Head of Department of administrative and financial management, NU "Lviv Polytechnic", Lviv \\ O. I. Bilyk \\ Ph.D. in Economics, Docent of the department of administrative and financial management, \\ NU "Lviv Polytechnic", Lviv \\ Ya. V. Levytska \\ PhD student of the Department of administrative and financial management, \\ NU "Lviv Polytechnic", Lviv
}

\section{THE CONDITION OF DIGITALIZATION IN UKRAINE}

В статті досліджено ичирові технологї як одна із значних складових нашого повсякденного життя. Поняття «цифрова економіка» розглядається не лише як торгівля за допомогою мережі Інтернет, а й як чинник збільшення інвестиційного клімату, як нова якість економіки або окремий сектор економіки. 3 огляду на це, авторами розглянуто основні визначення поняття циифрової економіки, описано феномен иүифрової економіки як окремої категорії, а також становлення та розвиток иифрової економіки в міжнародних відносинах та запропоноване власне визначення даного поняття. Зазначено позииію України щзодо поточного стану ичифрової економіки в світі. Вказано

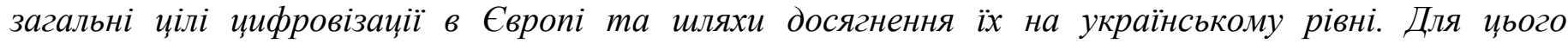
проаналізовано сучасний стан цифрровізації України за показниками щзорічних міжнародних рейтингів за останні три роки, які формуються на основних сукупних даних щодо використання інновацій, рівню розвитку інформаційно-комунікаційних технологій тощо. Сукупні дані визначають індекс мережевої готовності, індекс інновацій, індекс розвитку інформаційно-комунікаційних технологій, глобальної економічної конкурентоздатності, які за різними даними характеризують рівень української цифровізачії. Проведено аналіз статистичних показників використання Інтернету відповідно до кількості населення в краӥні, вартості використання Інтернет зв'язку в порівнянні із вартістю аналогів у світі та визначено види Інтернет-зв'язку, які доступні в Украӥні. Описано залежність між наявністю, доступністю Інтернет зв'язку та розвитком ициррової економіки. Визначено основний вид Інтернет-зв'язку, який впливає на рівень циифровізації національної економіки, можливості його отримання та якість. Виокремлено основні проблеми, які 
негативно впливають на Інтернет-зв'язок та гальмують інтенсивний розвиток иифрових проиесів. Запропоновано шляхи удосконалення Інтернет-зв'язку та розвитку Інтернет-мережі на території України, щз в свою чергу сприятиме розвитку національної ичифрової економіки в контексті розвитку цчифрової економіки Свропи.

The article explores digital technologies as one of the significant components of our daily lives. The term "digital economy" is seen not only as a trade through the Internet, but as a factor of the investment climate increasing, as a new quality of the economy or a separate sector of the economy. In view of this, the authors discuss the basic definitions of the term of digital economy, describe the phenomenon of digital economy as a separate category, and the creation and development of digital economy in international relations, and propose its own definition of this term. The authors identified Ukraine's position on the current state of the digital economy in the world. Indicated overall purposes of digitalization in Europe and ways to achieve them in the Ukrainian level. For this analysis of the current condition of digitalization in Ukraine on indicators of annual international rankings over the past three years, which are formed on the basic aggregate data on the use of innovation, level of development of information and communication technologies. Aggregated data determine the network readiness index, the innovation index, the index of development of information and communication technologies, global economic competitiveness, which according to various data characterize the level of Ukrainian digitalization. The statistics of Internet usage are analyzed according to the population in the country, the cost of using Internet connection in comparison with the cost of analogues in the world, and identified the types of Internet connection available in Ukraine. They described the relationship between the availability, accessibility of Internet connection and the development of the digital economy. Identified the basic type of Internet connection that affects the level of digitalization of the national economy, opportunities of its receipt and quality. Isolate the main problems that affect Internet connection and brake intensive development of digital processes. The authors suggested ways to improve Internet communications and the development of Internet network in Ukraine, which in turn will contribute to the development of national digital economy in the context of the digital economy in Europe.

Ключові слова: иүифрова економіка,ииифрові технологї, інтернет-комунікаиії,інновації, Інтернет зв'язок.

Key words: digital economy, digital technologies, Internet communications, innovations, Internet connection.

Постановка проблеми. Цифрові технології в сучасному світі є вимогою століття. Використання цифрових технологій охоплює всі сфери життя, а також дозволяє використовувати нові можливості. Медицина, освіта, промисловість, сфера обслуговування, зокрема створення високоточних обладнань для діагностики, аналізу та лікування, впровадження цифрових технологій на виробництві дозволяє збільшити обсяги виробництва, що своєю чергою збільшує темп розвитку економіки. Прогрес цифрових технологій на сьогоднішній день виводить сферу інтернет технологій на передову позицію за використанням інновацій. Діяльність цифрових технологій базується на дискретній системі, яка заснована на методах кодування та передачі інформації., що дозволяє проводити безліч різнопланових операцій за мінімальний проміжок часу. Феномен цифрових технологій полягає в тому, що це універсальні, швидкі та часто автоматизовані схеми роботи. Все ж таки основною функцією цифрових технологій поки що залишається обмін інформацією. Поширення цифрової інфраструктури такої як мобільні пристрої, бездротові мережі, персональні комп'ютери сприяє інтеграції їх також у економічне та суспільно-політичне життя усіх розвинених країн. Це сформувало нові стратегії розвитку міжнародної економіки. Високорозвинені країни та країни перехідної економіки останніми роками намагаються активно зменшити частку традиційної економіки за рахунок збільшення частки цифрової економіки. Для країн «Великої Сімки» цифрова економіка $є$ пріоритетним напрямком розвитку та стратегічною метою. Україна намагається впровадити використання цифрових технологій у всі сфери діяльності. Найбільші інвестиції спрямовані в економічний сектор, але існує низка проблем, які не сприяють швидкому та якісному темпу використання цифрових засобів на державному рівні.

Аналіз останніх досліджень та публікацій. Традиційні визначення цифрової економіки пов'язані із виробництвом, продажем та постачанням товарів та послуг через Інтернет. Однак, сучасні науковці намагаються розширити межі даного поняття. Джусов О. А., Альпаков С.С. визначають цифрову економіку як можливість збільшення привабливості інвестиційного клімату держави через призму міжнародних відносин [4]. Данніков О. В. та Січкаренко К. О. використовують поняття «інформаційно-мережева економіка» та характеризують їі через такі категорії: нова якість економічної науки та обробки інформації; сектори економіки, які повністю спираються на цифрові технології; сучасні соціально-інформаційні трансформації та парадигму розвитку країни, економіки та суспільства[3]. Гудзь О. Є. визначає, що переважно, науковці, під цифровою економікою розуміють виробництво, продаж і постачання продуктів за 
допомогою інформаційно-комунікаційних мереж [2].Коляденко С. В. описав визначення категорії «цифрова економіка» різними науковцями, які визначають ऑї як окремий вид економіки (Hopestone Kayiska Chavula, Abebe Cheko), мережу господарюючих суб'єктів, економічна форма (Alexandru Tugu), всі економічні процеси (Войнареко М. П., СкоробогатаЛ. B.) $[6]$.

Мета статті. Метою даної статті є аналіз сучасного стану цифровізації Українина основі міжнародних рейтингів та показників використання цифрових технологій, інновацій, визначення проблем, які гальмують розвиток цифровізації.

Виклад основного матеріалу. Термін «цифрова економіка» (Digitaleconomy) запропонував бізнес-аналітик Дон Тапскот (в деяких джерелах Тепскот). Визначення пояснює цифрову економіку як економічну діяльність, яка визначається через мережеву свідомість (networkedintelligence) та залежить від віртуальних технологій [12]. Сьогодні існують кілька синонімів до цифрової економіки: інтернет-економіка, нова економіка, веб-економіка. Загалом під цифровою економікою розуміють виробництво, продаж та постачання товарів та послуг за допомогою комп’ютерних мереж.

Цифрова економіка - це різновид ринку суб'єктів економічної системи на якому один, декілька або всі етапи господарських процесів здійснюються через комп'ютерні мережі; один із проявів економічної свободи, інноваційності та рівня розвитку економіки.

Якщо економісти нового світу почали виділяти в окрему категорію «цифрову економіку» в 90-х роках 20-го століття, то вагомість на європейському рівні дана категорія отримала в 2010 році під час розгляду Європейською Комісією «Цифрового порядку денного для Європи» (Digital Single Market Strategy) в рамках стратегії «Свропа 2020» [8]. Важливою складовою Цифрового порядку ЄС є створення Єдиного цифрового ринку (Digital Single Market). Україна, економічна політика якої спрямована на створення всіх умов для інтеграції до Європейського Союзу, також повинна враховувати окреслену стратегію Свропи. Першим кроком, на державному рівні, для розвитку цифрової економіки стало розроблення у 2016 році концептуальних засад цифровізації, які відображені у спільному проекті «Цифрова адженда України - 2020» [10]. Ініціатором цього проекту виступило Міністерство економічного розвитку та торгівлі України, а до розробки даного проекту були залучені представники державних органів влади, передових компаній у сфері використання цифрових технологій, громадських організацій, асоціацій, консалтингових груп, науковців, незалежних експертів та інші. Опираючись на вже існуючий проект реалізації цифрової економіки в Україні у 2018році Кабінет Міністрів України схвалив «Концепцію розвитку цифрової економіки та суспільства України на 2018-2020 роки»[1]. $[10][1]:$

Два основних документи, на які наша держава має орієнтуватися при цифровізації, визначають наступні іiі цілі

- цифрова модернізація усіх сфер життя та діяльності населення;

- трансформація традиційної економікиу конкурентоспроможну, ефективну та інвестиційно-привабливу;

- доступність цифрових технологій;

- підвищення економічних показників на міжнародному рівні;

- можливості для розвитку людських ресурсів, інноваційного підприємництва, цифрової індустрії.

Чітко визначені мета, принципи та напрямки цифрової модернізації, які потребують найшвидшої модернізації: освіта, медицина, транспортна інфраструктура, туризм, державне управління та охорона навколишнього середовища. Також зазначені бажані результати виконання розроблених проектів та концепцій у 2020 році, зокрема у «Концепції розвитку цифрової економіки України» вказані такі показники:

- 30 місця в рейтингу Networked Readiness Index (WEF);

- 40 місця у рейтингу Global Innovation Index (INSEAD, WIPO);

- 50 місця у рейтингу ICT Development Index (ITU);

- 60 місця у рейтингу Global Competitiveness Index (WEF).

Проте, у проекті «Цифровий порядок денний», який розроблявся ще у 2016 році були зазначені інші очікувані результатина основі глобальних індексів розвитку:

- у 2020 Україна — №40 у рейтингу Networked Readiness Index (WEF);

- у 2020 Україна — №40 у рейтингу Global Innovation Index (INSEAD, WIPO);

- у 2020 Україна - №50 у рейтингу Global Competitiveness Index (WEF).

На підставі цих очікуваних показників реалізації цифровізації в Україні проведемо аналіз оприлюднених показників, які оцінені світовими організаціями в період з 2016 по 2018 рік Табл.1.

Таблиця 1.

Показники глобальних індексів розвитку цифрової економіки для України

\begin{tabular}{|c|c|c|c|}
\hline Назва показника & 2016 & 2017 & 2018 \\
\hline Global Innovation Index (INSEAD, WIPO) & 56 & 50 & 43 \\
\hline ICT Development Index (ITU) & 78 & 79 & - \\
\hline Global Competitiveness Index (WEF) & 85 & 81 & 83 \\
\hline
\end{tabular}

Складена авторами на основі джерел [10][11][13][14]

Networked Readiness Index (WEF) - індекс мережевої готовності, показник яких характеризує рівень розвитку інформаційно-комунікаційних технологій [15]. Оцінка країн за цим показником проводиться Всесвітнім економічним форумом. Остання звітність була оприлюднена за 2016 рік, тому актуальні дані за аналізований період відсутні. Global Innovation Index (INSEAD, WIPO) - глобальний індекс інновацій, який оприлюднюється за підтримки світової організації інтелектуальної власності[13]. За даним рейтингом Україна за два роки стрімко покращила свою позицію і має тенденцію до отримання очікуваного результату у 2020 році. ICT Development Index (ITU) - індекс розвитку інформаційнокомунікаційних технологій, який характеризує досягнення країн у розвитку інформаційно-комунікаційних технологій, обраховується та оприлюднюється спеціальним підрозділом ООН[11]. Дані за 2018 рік поки що відсутні, однак бачимо, 
що за два роки рейтинг України кардинально не змінився. Global Competitiveness Index (WEF) - індекс глобальної економічної конкурентоздатності, обраховується та оприлюднюється Всесвітнім економічним форумом[14]. Рейтинг України за даним індексом є нестабільним. Досягнення очікуваного результату за два роки стає неможливим. На даний момент Україна зосереджена на розвитку інновацій, однак, поки що не застосовує їх на інструментпокращення економічних показників.

Оскільки цифрова економіка безпосередньо пов'язана із мережею Інтернет, то можливість ії розвитку прямо пропорційно залежить від його наявності, доступності, географічній місцевості населеного пункту тощо.

За даними американської компанії «We Are Social» та канадської компанії «Ноotsuite», які займаються глобальними соціологічними дослідженнями, і щороку оприлюднюють результати цифровізації в світі за різними показниками відповідно до кількості населення. На основі показників звітів даних компаній, проаналізовано стан цифровізації в Україні.

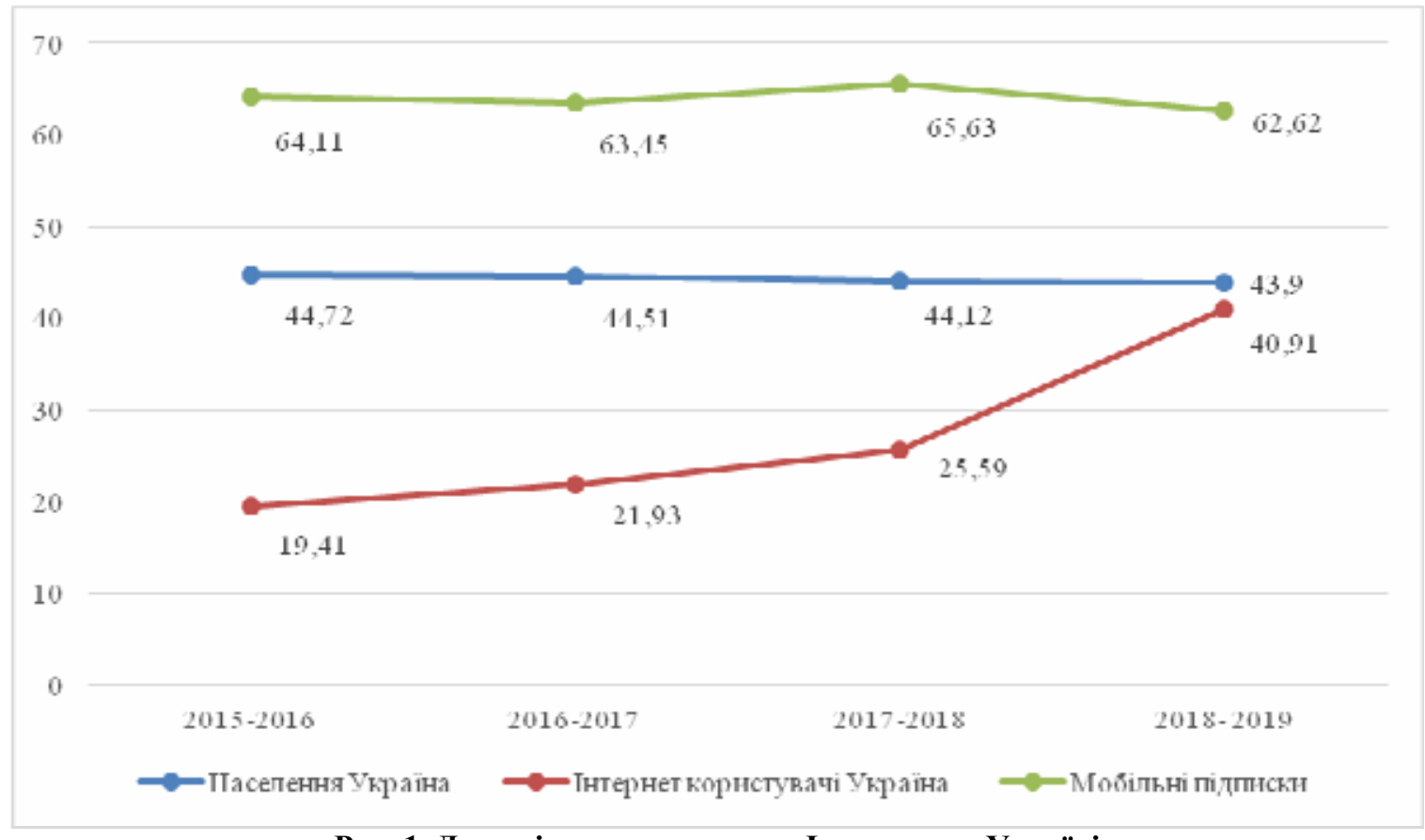

Рис. 1. Динаміка використання Інтернету в Україні

проілюстрована авторами на основі даних джерел [16][17][18][19]

Як видно з Рис. 1. Кількість користувачів інтернетом в Україні збільшується щорічно. Аналіз у відсотковому відношенні показує, що в період із січня 2015 по січень 2016 в Україні частка інтернет користувачів відносно населення країни складала 43, 4 \%, то за три наступні проаналізовані періоди вона складала 49,2\%, 58\% та 93,1 \% відповідно. Коливання кількості населення в Україні впродовж чотирьох періодів зменшилося на 0,82 млн осіб, що є цілком прийнятним для об'єктивних результатів.

Також за даними досліджень впродовж чотирьох років в Україні кількість мобільних користувачів значно перевищує населення країни загалом, це пов'язано із тим, що значна частина населення України має в користування декількома мобільними пристроями (смартфон, планшет).

Можливість використовувати Інтернет пристрої для потреб суспільства визначається наявністю Інтернет зв'язку.

Види Інтернет зв’язку в Україні [7]:

- кабельний зв'язок;

- мобільний Інтернет»

- Інтернет по радіоканалу;

- супутниковий Інтернет.

За даними Інтернет Асоціації України на сьогодні в Україні нараховується понад 4 тис. постачальників інтернет зв’язку, однак для стабільності у розвитку цифрової економіки та цифрових потреб суспільства необхідна якість та швидкість інтернет зв'язку.

32015 року в Україні масштабно почали запускати 3G зв'язок через найбільших мобільних операторів (Київстар, VodafonУкраїна та Lifecell), оскільки в період з 2007 по 2015 рік в Україні мобільний 3G зв'язок надавали лише кілька операторів (Укртелеком, Реoplenet, Інтертелеком, ТриМоб).

За період 2018 році Україна значно збільшила можливості доступу до якісного і швидкісного Інтернету, зокрема впровадження мобільного 4-G інтернет-зв'язку.

Результати дослідження Cable.co.uk, британського провайдера, який проводить аналіз доступності Інтернету у 230 країнах світу, показують, що мобільний Інтернет в Україні є найдешевшим в Свропі та четвертим за доступністю в світі [5]. Дані зібрані у жовтні-листопаді 2018 року. Це свідчить про те, що в нашій державі створюється достатня кількість умов для забезпечення доступності хоча б мобільного Інтернет зв’язку кожному громадянину. Однак, покриття якісного інтернет-зв'язку не охоплює всю територію України i, як наслідок, зменшує швидкість розвитку цифрової економіки. 
Поліпшення якості мобільного інтернету можливе за рахунок оновлення інфраструктурного забезпечення, інвестицій для підтримки існуючої якості та розширення каналів зв'язку. Загалом ринок інтернет послуг переповнений значною кількістю конкурентів, оскільки відсутні бар'єри для входження на ринок. Існує багато альтернативних Інтернет провайдерів, які надають послуги низької якості, але за зниженими цінами в порівнянні із мобільним інтернетом. Для покращення інтернет зв'язку на території України та залученню більшої кількості абонентів мобільним операторам необхідно провести оптимізацію мереж. Необхідно врахувати території, де відсутнє покриття мобільної інтернет мережі і встановити базові станції. Базові станції є основою для збільшення діапазону дії мережі.

Сьогодні в Україні кількість цифрових послуг розширюється з кожним днем, але можливості скористатися ними будь-де і будь-коли поки що відсутня. Однією із найбільших проблем виступає відсутність інтернет-комунікацій у малих населених пунктах, частині автомобільних та залізничних шляхів, гірській місцевості тощо. Покращення інтернет-мережі в Україні дозволить більшій кількості населення використовувати електронні можливості, що збільшить попит та конкуренцію в цифровій економіці. Як наслідок - підвищення індексів розвитку цифрової економіці держави.

Висновки 3 даного дослідження та перспективи подальших досліджень: в Україні створюються сприятливі умови для розвитку цифрової економічної інфраструктури, але існує низка технічних особливостей, які перешкоджають доступності засобів комунікацій для всього населення країни і будь-якій іiі точці. Для цього необхідно державну економічну політику спрямувати на стимулювання продуктивності завдяки інноваціям. Світова практика показує що технологічні інновації безпосередньо пов'язані із позитивними економічними показниками.

\section{Література.}

1. Розпорядження Кабінету Міністрів України «Про схвалення Концепції розвитку цифрової економіки та суспільства України на 2018-2020 роки та затвердження плану заходів щодо ії реалізації»від 17 січня 2018 р. № 67-р. [Електронний peсурс] - URL: https://zakon.rada.gov.ua/laws/show/67-2018-p/ed20180117\#n23

2. Гудзь О. Є. Цифрова економіка: зміна цінностей та орієнтирів управління підприємствами. «Економіка. Менеджмент. Бізнес» № 2 (24), 2018

3. Данніков О.В, Січкаренко К. О. Концептуальні засади цифровізації економіки України. «Інфраструктура ринку», №17, ст. 73-80, 2018.

4. Джусов О. А., Альпаков С. С. Цифрова економіка: структурні зрушення на міжнародному ринку капіталу. Міжнародні відносини серія «Економічні науки» №9, 2016

5. Інтернет провайдер Великої Британії «Cable», вартість мобільних даних у всьому світі [Електронний ресурс] Режим доступу: https://www.cable.co.uk/mobiles/worldwide-data-pricing/

6. Коляденко С. В. Цифрова економіка: передумови та етапи становлення в Україні і у світі / С. В. Коляденко // Економіка. Фінанси. Менеджмент: актуальні питання науки і практики. -2016. - № 6. - С. 105-112.

7. Короткий посібник з питань видів Інтернет зв'язку [Електронний ресурc] - URL: https://ula.org.ua

8. Повідомлення Європейської комісії для Європейського парламенту, Ради економічного і соціального комітету та Комітету регіонів. Європейська комісія, Брюссель, 19.05. 2010 [Електронний pecypc] - URL: eump.org/system/Цифровий\%20порядок\%20денний\%20для\%20 Свропи.pdf

9. Стан інноваційної діяльності та діяльності у сфері трансферу технологій в Україні у 2017 році: аналітична довідка / Т.В. Писаренко, Т.К. Кваша та ін. - К.: УкрIНТЕI, 2018. - 98 с.

10. Цифрова адженда України - 2020. Концептуальні засади. Першочергові сфери, ініціативи, проекти цифровізації України до 2020 року. / HITECH office. грудень 2016. 90 с. [Електронний ресурс] - URL: https://ucci.org.ua/uploads/files/58e78ee3c3922.pdf.

11. International Telecommunications Union ICT Development Index 2016-2017 [Електронний ресурс]. - Режим доступу: https://www.itu.int/net4/ITU-D/idi/2017/index.html

12. Tapscott, D. The Digital Economy: PromiseandPerilintheAgeofNetworkedIntelligence. McGraw-Hill, 342, 1995

13. The Global Innovation Index 2018. [Електронний ресурс]. - Режим доступу: https://www.globalinnovationindex.org/gii-2018-report

14. The Global Competitiveness Report 2017-2018. [Електронний ресурс]. - Режим доступу: http://www3.weforum.org/docs/GCR20172018/05FullReport/TheGlobalCompetitivenessReport2017-2018.pdf

15. The Networked Readiness Index [Електронний ресурс]. - Режим доступу: http://reports.weforum.org/globalinformation-technology-report-2016/networked-readiness-index/?doing_wp_cron=1558349353.7612900733947753906250 2019-global

16. We Are Social USA Digital 2019 Global [Електронний ресурс]. - Режим доступу: https://wearesocial.com/digital2018-global

17. We Are Social USA Digital 2018 Global [Електронний ресурс]. - Режим доступу: https://wearesocial.com/digital2017-global

18. We Are Social USA Digital 2017 Global [Електронний ресурс]. - Режим доступу: https://wearesocial.com/digital-

19. We Are Social USA Digital 2016 Global [Електронний ресурс]. - Режим доступу: https://wearesocial.com/digital$\underline{\text { 2016-global }}$

\section{References.}

1. Cabinet of Ministers of Ukraine (2018), Resolution "On approval of the Concept of development of the digital economy and society of Ukraine for 2018-2020 and approval of the plan of measures for its implementation", available at: https://zakon.rada.gov.ua/laws/show/67-2018-r/ed20180117\#n23 (Accessed 15 Sept 2019).

2. Hudz', O. Ye. (2018), "Digital Economy: Changing the Values and Guidelines of Enterprise Management", Ekonomika. Menedzhment. Biznes, vol. 2 (24). 
3. Dannikov, O.V. and Sichkarenko, K. O. (2018), "Conceptual bases of digitalization of economy of Ukraine", Infrastruktura rynku, vol.17, pp. 73-80.

4. Dzhusov, O. A. and Al'pakov, S. S. (2016), "The digital economy: structural shifts in the international capital market", Mizhnarodni vidnosyny seriia Ekonomichni nauky, vol.9.

5. Cable.co.uk (2019), "Worldwide mobile data pricing: The cost of 1GB of mobile data in 230 countries", available at: https://www.cable.co.uk/mobiles/worldwide-data-pricing/ (Accessed 15 Sept 2019).

6. Koliadenko, S. V. (2016), "The digital economy: preconditions and stages of formation in Ukraine and in the world", Ekonomika. Finansy. Menedzhment: aktual'ni pytannia nauky i praktyky, vol. 6, pp. 105-112.

7. Ukrainian Library Association (2019), "A quick guide to the types of internet connection", available at: https://ula.org.ua (Accessed 15 Sept 2019).

8. European Commission (2010), "'Communication from the European Commission to the European Parliament, the Council of the Economic and Social Committee and the Committee of the Regions, available at: eump.org/system/Tsyfrovyj\%20poriadok\%20dennyj\%20dlia\%20 Yevropy.pdf (Accessed 15 Sept 2019).

9. Pysarenko, T.V. and Kvasha, T.K. (2018), Stan innovatsijnoi diial'nosti ta diial'nosti u sferi transferu tekhnolohij v Ukraini u 2017 rotsi [State of innovation and technology transfer activities in Ukraine in 2017], UkrINTEI, Kyiv, Ukraine.

10. HITECH office (2016), "Digital Agenda of Ukraine - 2020. Conceptual Background. Priority areas, initiatives, projects for digitization of Ukraine until 2020", available at: https://ucci.org.ua/uploads/files/58e 78ee3c3922.pdf (Accessed 15 Sept 2019).

11. International Telecommunications Union (2017), “ICT Development Index 2016-2017”, available at: https://www.itu.int/net4/ITU-D/idi/2017/index.html (Accessed 15 Sept 2019). NY, USA.

12. Tapscott, D. (1995), The Digital Economy: Promise and Perilin the Age of Network edIntelligence, McGraw-Hill, 15 Sept 2019)

13. The Global Innovation Index (2018), available at: https:/www.globalinnovationindex.org/gii-2018-report (Accessed

14. World Economic Forum (2019), "The Global Competitiveness Report 2017-2018", available at: http://www3.weforum.org/docs/GCR20172018/05FullReport/TheGlobalCompetitivenessReport2017-2018.pdf (Accessed 15 Sept 2019).

15. World Economic Forum (2016), “The Networked Readiness Index”, available at: http://reports.weforum.org/globalinformation-technology-report-2016/networked-readiness-index/?doing_wp_cron=1558349353.7612900733947753906250

(Accessed 15 Sept 2019).

16. We Are Social USA (2019), "Digital 2019 Global”, available at: https://wearesocial.com/digital-2019-global (Accessed 15 Sept 2019).

17. We Are Social USA (2018), "Digital 2018 Global”, available at: https://wearesocial.com/digital-2018-global (Accessed 15 Sept 2019).

18. We Are Social USA (2017), "Digital 2017 Global”, available at: https://wearesocial.com/digital-2017-global (Accessed 15 Sept 2019). (), “”, available at: (Accessed 15 Sept 2019).

19. We Are Social USA (2016), "Digital 2016 Global", available at: https://wearesocial.com/digital-2016-global (Accessed 15 Sept 2019). (), “”, available at: (Accessed 15 Sept 2019). 